\title{
The Influence of Silicon Content on Recrystallization of Twin-Roll Cast Aluminum Alloys for Heat Exchangers
}

\author{
M. Poková ${ }^{a, b}$, M. Cieslar ${ }^{a, *}$ AND J. LACAZE ${ }^{b}$ \\ ${ }^{a}$ Charles University in Prague, Faculty of Mathematics and Physics, Ke Karlovu 5, 12116 Prague 2, Czech Republic \\ ${ }^{b}$ CIRIMAT, ENSIACET, 5 allée Emile Monso, B.P. 44362, 31030 Toulouse cedex 4, France
}

\begin{abstract}
Thin foils of aluminum alloys are commonly used in automotive industry for manufacturing heat exchangers. Use of twin-roll casting instead of direct-chill casting requires modifications in the manufacturing process and use of improved materials. In the present study, the evolution in microstructure and mechanical properties during isochronal annealing of two AW3003-based alloys differing in silicon content was monitored. The silicon influenced both the microhardness and precipitation kinetics during annealing, but not the recrystallization temperature. Precipitation of cubic $\alpha-\mathrm{Al}_{15}(\mathrm{Mn}, \mathrm{Fe})_{3} \mathrm{Si}_{2}$ phase occurred in two steps in the material with higher Si content, while mainly precipitates of $\mathrm{Al}_{6}(\mathrm{Mn}, \mathrm{Fe})$ phase formed in the second material in a broad temperature interval, preferentially at grain boundaries.
\end{abstract}

PACS: 81.40.Ef, 68.37.Lp, 81.30.Mh

\section{Introduction}

Foils from Al-Mn based alloys are frequently used as fins in automotive heat exchangers. The manufacturing of such fins is a complex process which consists of twin-roll casting, several cold-rolling and annealing steps, forming and brazing. The microstructure and mechanical properties of the final fins are influenced by all these steps so the thorough understanding of their respective effect is necessary to provide products with the properties required by industry: good strength, ductility, corrosion and sagging resistance.

Thanks to higher cooling rates, materials prepared by twin-roll casting exhibit higher solid solution supersaturation in the as-cast state than the direct-chill cast ones. Next to the primary particles, which appeared during the casting process, new dispersoids precipitate during annealing at elevated temperatures [1]. In AW3003 alloys, the temperature of main precipitation has been observed between 300 and $500{ }^{\circ} \mathrm{C}[2-6]$.

The composition and morphology of dispersoids depend on the specific content in alloying elements of each alloy. The two phases most often observed in Al$\mathrm{Mn}-\mathrm{Fe}-\mathrm{Si}$ alloys are orthorhombic $\mathrm{Al}_{6}(\mathrm{Mn}, \mathrm{Fe})$ and $\mathrm{cu}-$ bic $\alpha-\mathrm{Al}_{15}(\mathrm{Mn}, \mathrm{Fe})_{3} \mathrm{Si}_{2}[2,7]$, but others like hexagonal $\alpha-\mathrm{Al}_{8} \mathrm{Fe}_{2} \mathrm{Si}$ have also been reported in the literature [7]. Which one is predominant depends mainly on the silicon content [8-10]. It may be mentioned that, depending on the $\mathrm{Mn}: \mathrm{Fe}$ ratio, the $\alpha-\mathrm{Al}_{15}(\mathrm{Mn}, \mathrm{Fe})_{3} \mathrm{Si}_{2}$ phase exists in two different variants: simple cubic when Mn pre-

\footnotetext{
* corresponding author; e-mail: miroslav.cieslar@mff.cuni.cz
}

vails and body centered cubic otherwise [11-13]. During heat treatment, both primary particles and dispersoids of $\mathrm{Al}_{6}(\mathrm{Mn}, \mathrm{Fe})$ may transform to $\alpha-\mathrm{Al}_{15}(\mathrm{Mn}, \mathrm{Fe})_{3} \mathrm{Si}_{2}$ thanks to diffusion of silicon and manganese that is enhanced with increasing temperature $[8,11,14]$.

Cold-rolled materials contain a high number of dislocations and stored deformation energy which can be released during recrystallization ( $\mathrm{RX})$. The temperature and the extent of RX are influenced by the amount of strain introduced into the material during cold-rolling [15] and also by the size and distribution of particles present in the material. It has been documented that large particles promote RX by particle stimulated nucleation of new grains but small dispersoids retard RX by exerting the Zener drag on moving grain boundaries $[16,17]$. Precipitation and recrystallization can affect each other [18] as dislocations may serve as preferential sites for heterogeneous nucleation and thus RX could impede precipitation. On the other hand, precipitation prior to RX leads to the formation of fine particles which may retard $\mathrm{RX}$.

The present contribution is a study of microstructure and mechanical properties evolution in two twin-roll cast alloys from the AW3003 series differing in silicon content during isochronal annealing that have been cold-rolled to $0.4 \mathrm{~mm}$.

\section{Experimental}

The two alloys investigated were alloy $\mathrm{H}$, high in $\mathrm{Si}$ containing $0.90 \mathrm{Mn}, 0.53 \mathrm{Fe}$ and $0.50 \mathrm{Si}$ and alloy L, with $0.86 \mathrm{Mn}, 0.61 \mathrm{Fe}$ and $0.10 \mathrm{Si}$ (in wt\%). The alloys were twin-roll cast from the melt into $8.5 \mathrm{~mm}$ thick 
sheets, then cold-rolled in several steps to the thickness of $0.4 \mathrm{~mm}$. The specimens from the sheets were subjected to a step-by-step isochronal annealing in laboratory conditions. For this, the specimens were put into a pre-heated furnace and hold for $20 \mathrm{~min}$ at the temperature. They were then water quenched and their electrical resistivity $\rho$ in liquid nitrogen was measured. After this measurement, the specimens were put again for 20 min into the furnace with temperature increased by $20^{\circ} \mathrm{C}$. The temperature range for the annealing thus investigated was from room temperature to $620^{\circ} \mathrm{C}$

To estimate the main temperature range of solid-solution decomposition by precipitation, electrical resistivity $\rho$ in liquid nitrogen was measured using DC four-point method with a dummy specimen in series [19]. Electrical resistivity $\rho$ is a material's property, which is very sensitive to the concentration of solute atoms in the metallic matrix of a metal. As such it helps evaluating the temperature ranges of main solute redistribution in the material during annealing. In the resistivity annealing spectrum $-(\mathrm{d} \rho / \mathrm{d} T) / \rho_{0}$, which is the negative normalized derivative of $\rho$ with respect to the temperature $T$ with $\rho_{0}$ being the resistivity of the non-annealed material, a local maximum corresponds to the precipitation of one or several new phases while particle dissolution can be associated to a local minimum.

Softening of the materials was monitored by measurements of the Vickers microhardness and these measurements provided an estimate of the temperature interval for recrystallization. Light microscopy and transmission electron microscopy (TEM) were used to study the grain structure and then the substructure of deformed and annealed materials as well as the phase composition - nature of primary particles and precipitates formed during annealing. The microstructure observations and electron diffraction analysis of particles were carried out on a JEOL JEM 2000 FX microscope operating at $200 \mathrm{kV}$ and equipped with an X-ray energy dispersive spectrometer LINK AN 10000.

\section{Results}

The resistivity annealing spectra (Fig. 1) of the $\mathrm{H}$ and L samples exhibit some differences. The alloy $\mathrm{L}$ with lower Si content has one broad peak with a maximum at $300^{\circ} \mathrm{C}$. The peak in the alloy $\mathrm{H}$ is split into two sub-stages at about 300 and $400{ }^{\circ} \mathrm{C}$. At temperatures above $450^{\circ} \mathrm{C}$, we can observe two minima in both alloys which are however more pronounced in the material with higher Si content.

The evolution of the Vickers microhardness (Fig. 2) is similar for both alloys, though the $\mathrm{H}$ alloy shows values higher by approximately $10 \%$ than those recorded on the L alloy. After moderate increase at lower annealing temperatures (around $200^{\circ} \mathrm{C}$ ), significant drop occurs between $240^{\circ} \mathrm{C}$ and $440^{\circ} \mathrm{C}$, which levels off at higher temperatures.

Because of cold-rolling to $0.4 \mathrm{~mm}$, both materials contain heavily deformed grains that are elongated in the

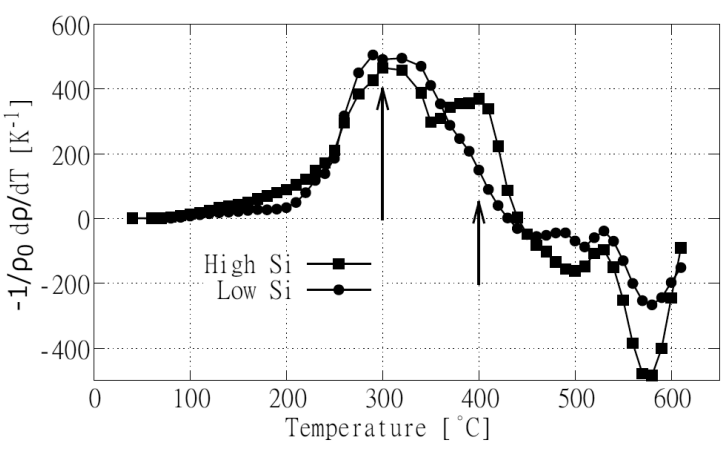

Fig. 1. Resistivity spectra of two materials differing in Si content as obtained by the means of isochronal annealing. Two precipitation peaks are indicated with arrows for the material $\mathrm{H}$ with higher $\mathrm{Si}$ content around 300 and $400{ }^{\circ} \mathrm{C}$. The second peak is suppressed in the material L with lower Si content.

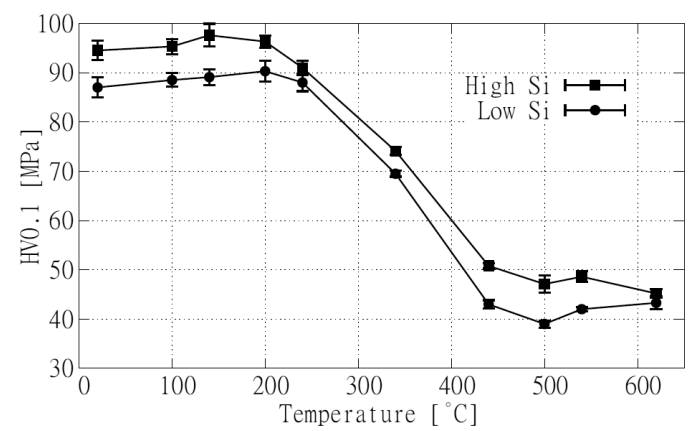

Fig. 2. Microhardness evolution of the two alloys during isochronal annealing up to $620^{\circ} \mathrm{C}$. Significant drop of hardness between $240^{\circ} \mathrm{C}$ and $440{ }^{\circ} \mathrm{C}$ corresponds to the recovery of dislocation substructure and recrystallization.

rolling direction (Fig. 3). This structure does not change significantly until $340^{\circ} \mathrm{C}$. At $440^{\circ} \mathrm{C}$, after the drop in microhardness and the maximum in resistivity annealing spectrum, both materials are fully recrystallized. New recrystallized grains have formed with a width of approximately $50 \mu \mathrm{m}$ and a length in rolling direction up to $1 \mathrm{~mm}$. Further annealing did not lead to observable grain coarsening, in apparent agreement with the level-off of the hardness change above $440^{\circ} \mathrm{C}$.

TEM observations revealed that, in the initial state after rolling to the thickness of $0.4 \mathrm{~mm}$, both alloys contain high density of dislocations arranged in a cell structure with cell diameter approximately $300 \mathrm{~nm}$. This is illustrated in Fig. 4 (left) for alloy H. The selected area electron diffraction analysis has shown that the primary particles are predominantly the cubic $\alpha-\mathrm{Al}_{15}(\mathrm{Mn}, \mathrm{Fe})_{3} \mathrm{Si}_{2}$ in the $\mathrm{H}$ material and a mixture of hexagonal $\alpha-\mathrm{Al}_{8} \mathrm{Fe}_{2} \mathrm{Si}$ and cubic $\alpha-\mathrm{Al}_{15}(\mathrm{Mn}, \mathrm{Fe})_{3} \mathrm{Si}_{2}$ with significant fraction of orthorhombic $\mathrm{Al}_{6}(\mathrm{Mn}, \mathrm{Fe})$ phase in the $\mathrm{L}$ material. Often they are clustered in two-phase colonies (Fig. 5, left).

After annealing up to $200^{\circ} \mathrm{C}$, a partial recovery of dislocation structure occurred but the dislocation density 


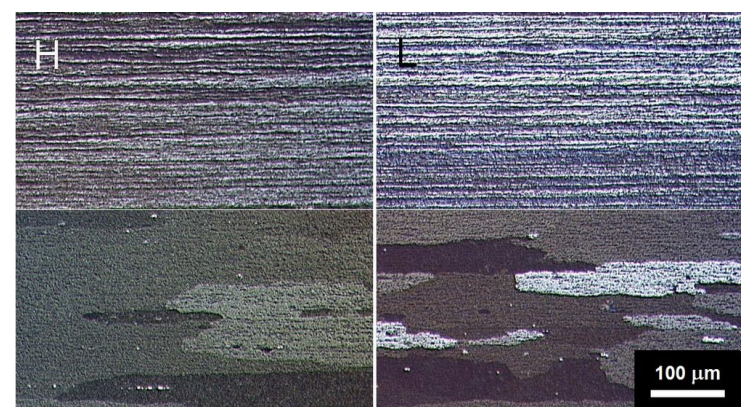

Fig. 3. Optical micrographs taken in polarized light. Highly deformed grains after rolling (top) and new recrystallized grains elongated in rolling direction after annealing up to $440{ }^{\circ} \mathrm{C}$ (bottom). The material $\mathrm{H}$ richer in $\mathrm{Si}$ on the left side, the material $\mathrm{L}$ with lower $\mathrm{Si}$ amount on the right.

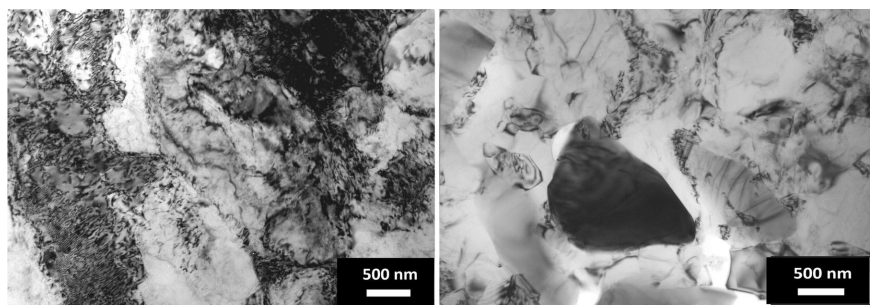

Fig. 4. TEM micrograph of the initial microstructure of the $\mathrm{H}$ alloy. High density of dislocations after cold-rolling (left) and a primary particle with cubic structure $\alpha-\mathrm{Al}_{15}(\mathrm{Mn}, \mathrm{Fe})_{3} \mathrm{Si}_{2}$ (right).

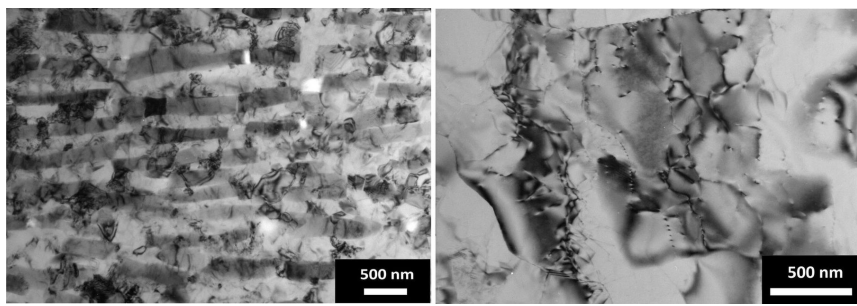

Fig. 5. The material L with lower silicon content: the eutectic colonies formed during casting (left) and partially recovered dislocation substructure after annealing to $200^{\circ} \mathrm{C}$ (right).

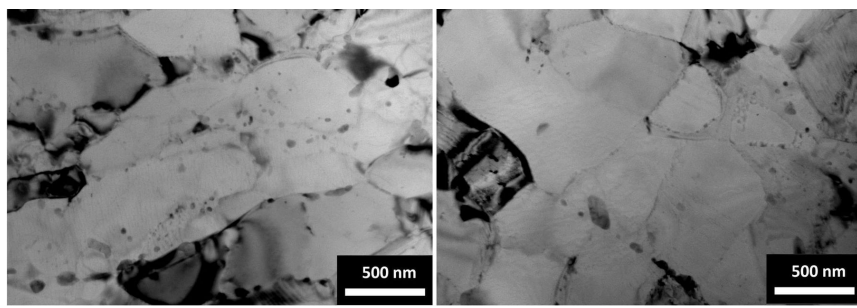

Fig. 6. Materials annealed to $340{ }^{\circ} \mathrm{C}$, dispersoids formed at the (sub)grain boundaries. In the material $\mathrm{H}$ with higher $\mathrm{Si}$ content they are body centered cubic $\alpha-\mathrm{Al}_{15}(\mathrm{Mn}, \mathrm{Fe})_{3} \mathrm{Si}_{2}$ phase (left); orthorhombic $\mathrm{Al}_{6}(\mathrm{Mn}, \mathrm{Fe})$ phase formed in the material $\mathrm{L}$ with lower Si (right). still remained relatively high in the $\mathrm{H}$ specimen as compared to the $\mathrm{L}$ one that is illustrated in Fig. 5 (right). The dislocations recovery and the cells transformation into subgrain boundaries was observed in specimens annealed up to $340^{\circ} \mathrm{C}$. New dispersoids of diameter 10 $50 \mathrm{~nm}$ precipitated heterogeneously on (sub)grain boundaries. In the material $\mathrm{H}$, they are of body centered cubic $\alpha-\mathrm{Al}_{15}(\mathrm{Mn}, \mathrm{Fe})_{3} \mathrm{Si}_{2}$ (Fig. 6, left), while in the material $\mathrm{L}$ orthorhombic $\mathrm{Al}_{6}(\mathrm{Mn}, \mathrm{Fe})$ phase without Si prevails (Fig. 6, right). Moreover, in the material $\mathrm{L}$, the primary particles often transformed from the hexagonal $\alpha-\mathrm{Al}_{8} \mathrm{Fe}_{2} \mathrm{Si}$ phase to cubic $\alpha-\mathrm{Al}_{15}(\mathrm{Mn}, \mathrm{Fe})_{3} \mathrm{Si}_{2}$.

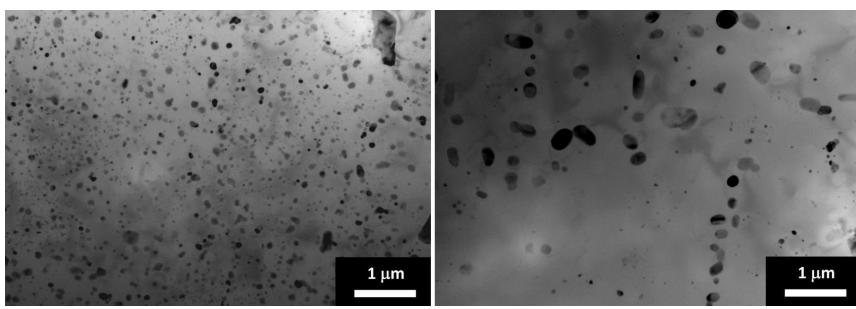

Fig. 7. Left: high density of dispersoids of simple cubic $\alpha-\mathrm{Al}_{15}(\mathrm{Mn}, \mathrm{Fe})_{3} \mathrm{Si}_{2}$ phase formed in the grain interior at $440{ }^{\circ} \mathrm{C}$, surrounded by slightly coarser particles of bcc phase on former grain boundaries in the material H. Right: coarser dispersoids of $\mathrm{Al}_{6}(\mathrm{Mn}, \mathrm{Fe})$ phase on former grain boundaries in the material $\mathrm{L}$.
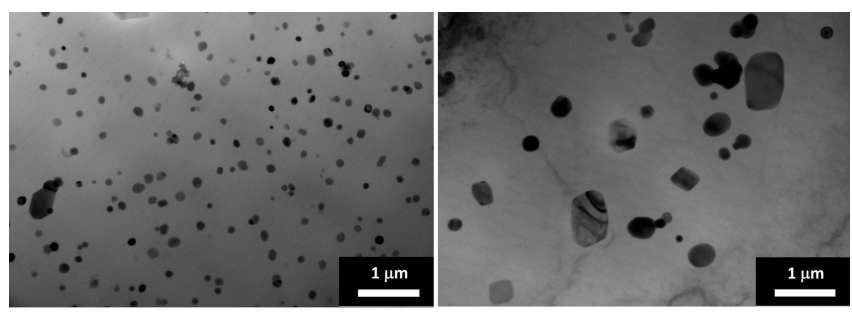

Fig. 8. The microstructure after annealing to $620^{\circ} \mathrm{C}$ : the precipitates are coarser and their number density is lower than at $440{ }^{\circ} \mathrm{C}$. The number of precipitates is much lower in the $\mathrm{L}$ material (right) as compared to the $\mathrm{H}$ material (left).

At $440^{\circ} \mathrm{C}$, both materials are fully recrystallized and show coarse grains. A high number of new dispersoids of $\alpha-\mathrm{Al}_{15}(\mathrm{Mn}, \mathrm{Fe})_{3} \mathrm{Si}_{2}$ phase formed in the alloy $\mathrm{H}$ in the bulk volume of the matrix (Fig. 7, left). The new dispersoids have simple cubic structure, unlike those which precipitated at lower temperatures at grain boundaries which showed a body centered cubic structure. In the material with lower Si content only a limited number of new dispersoids of the simple cubic $\alpha-\mathrm{Al}_{15}(\mathrm{Mn}, \mathrm{Fe})_{3} \mathrm{Si}_{2}$ phase was detected while coarsening of dispersoids of the $\mathrm{Al}_{6}(\mathrm{Mn}, \mathrm{Fe})$ phase located on former grain boundaries was the dominant process (Fig. 7, right).

At temperatures above $540^{\circ} \mathrm{C}$, precipitates coarsening occurred in both materials, with the smaller ones dissolving back to the solid solution. At $620^{\circ} \mathrm{C}$, only large 
particles were observed in the $\mathrm{L}$ material when the $\mathrm{H}$ material still exhibits the presence of a large number of coarse precipitates of the cubic $\alpha-\mathrm{Al}_{15}(\mathrm{Mn}, \mathrm{Fe})_{3} \mathrm{Si}_{2}$ phase (Fig. 8)

\section{Discussion}

After casting and rolling to $0.4 \mathrm{~mm}$, the materials exhibit high density of dislocations and flat grains elongated in rolling direction. Coarse primary particles could be found within materials, with cubic structure $\alpha-\mathrm{Al}_{15}(\mathrm{Mn}, \mathrm{Fe})_{3} \mathrm{Si}_{2}$ in the material $\mathrm{H}$ with higher Si content, and hexagonal $\alpha-\mathrm{Al}_{8} \mathrm{Fe}_{2} \mathrm{Si}$ and orthorhombic $\mathrm{Al}_{6}(\mathrm{Mn}, \mathrm{Fe})$ in $\mathrm{L}$ material. Only moderate changes occurred in the resistivity and microhardness during annealing up to $200^{\circ} \mathrm{C}$. Small increase in the resistivity annealing spectrum is associated with partial dislocation redistribution which might be accompanied by depletion of the matrix in Si atoms. During this stage, silicon either forms clusters or enrich primary particles [2]. Contribution from manganese is not of much importance because of its lower diffusion coefficient at $200^{\circ} \mathrm{C}$ as compared to silicon [20, 21].

The moderate increase of the microhardness which is observed at low annealing temperatures was most probably caused by the solute clustering. This effect prevailed over dislocation recovery that also contributes to the lowering of the resistivity, but would result at the same time in a decrease of the microhardness. Generally, recovery of the dislocation substructure results in the deterioration of mechanical properties. However, a different phenomenon has also been reported in the fine-grained aluminum, namely an increase of the microhardness during annealing and recovery $[22,23]$. Therefore the exact mechanism responsible for the resistivity and the microhardness changes below $200{ }^{\circ} \mathrm{C}$ is worth of further investigation.

Between 200 and $440^{\circ} \mathrm{C}$, global maxima occurred in the resistivity annealing spectra which correspond to the depletion of the matrix in solute atoms because of massive precipitation of new particles. This process is split into two steps for the $\mathrm{H}$ material: firstly the precipitates form at subgrain and grain boundaries, and, secondly, after recrystallization also inside the grains. On the other hand, only one broad maximum was observed in the $\mathrm{L}$ material.

The main drop in microhardness is connected with the recrystallization. Thanks to the recovery of the dislocation structure and formation of new grains with low density of dislocations, the material strength decreased significantly. Silicon content does not appear to affect the recrystallization temperature, though material $\mathrm{H}$ exhibits higher microhardness values at all annealing temperatures presumably because of solid solution hardening. The leveling-off of the microhardness at high temperatures can be attributed to the dissolution of small precipitates back into the solid solution and also to partial dissolution of primary particles.
The first precipitation stage occurs before recrystallization, when the materials contain high density of dislocations and (sub)grain boundaries which serve as preferential nucleation sites. After recrystallization, homogeneous precipitation of $\alpha-\mathrm{Al}_{15}(\mathrm{Mn}, \mathrm{Fe})_{3} \mathrm{Si}_{2}$ phase within the grains proceeds in the material with higher $\mathrm{Si}$. This is associated with the second peak in the resistivity spectrum and leads to very limited particle coarsening in this alloy at that stage. On the contrary, the phase $\mathrm{Al}_{6}(\mathrm{Mn}, \mathrm{Fe})$ formed at (sub)grain boundaries in the material L does not appear to easily nucleate homogeneously inside the grains. As a consequence, coarsening of already existing dispersoids is the dominant process when grain growth has started in this alloy, and this is thought to explain the broadening of the precipitation peak in the L material.

Final minimum in the resistivity annealing spectra, which is more pronounced in the Si-rich material, is caused by dissolution of the second phase particles back to the solid solution, which is accompanied by coarsening of some dispersoids and primary particles.

Recovery of the dislocation substructure, recrystallization and grain coarsening are expected to have the main impact on the evolution of the microhardness during annealing. Nevertheless, these changes of deformed microstructure are also affected by the particle redistribution within the material. Thanks to the solute depletion of the matrix, the migration of dislocations and grain boundaries is enhanced and the recrystallization, leading to material softening, is accelerated.

\section{Summary}

In the present paper, two AW3003 alloys, differing in their silicon content, were studied through isochronal annealing from room temperature to $620^{\circ} \mathrm{C}$. The alloy richer in $\mathrm{Si}$ exhibits slightly higher microhardness values and showed a two-step precipitation sequence centered around $300^{\circ} \mathrm{C}$ and $400^{\circ} \mathrm{C}$. First the body centered cubic $\alpha-\mathrm{Al}_{15}(\mathrm{Mn}, \mathrm{Fe})_{3} \mathrm{Si}_{2}$ phase precipitated at grain boundaries and after recrystallization new dispersoids of the simple cubic $\alpha-\mathrm{Al}_{15}(\mathrm{Mn}, \mathrm{Fe})_{3} \mathrm{Si}_{2}$ phase formed in the whole volume of the matrix. In the material with lower Si content, the $\mathrm{Al}_{6}(\mathrm{Mn}, \mathrm{Fe})$ dispersoids precipitated around $300{ }^{\circ} \mathrm{C}$ at grain boundaries and their coarsening was the dominant process during further annealing. Only limited number of the simple cubic $\alpha-\mathrm{Al}_{15}(\mathrm{Mn}, \mathrm{Fe})_{3} \mathrm{Si}_{2}$ dispersoids precipitated in this latter material.

The high dislocation density, resulting from the cold-rolling, recovered and both materials fully recrystallized below $440^{\circ} \mathrm{C}$, but elongation in the rolling direction still remained apparent in the grain structure even at high annealing temperatures.

\section{Acknowledgments}

This work was financially supported by grants GAUK 106-10/251153 and SVV-2010-261303 and scholarships 
from French government and AL INVEST Břidličná, a.s., Czech Republic, who also provided all experimental materials. The work is part of a research program MSM 0021620834 that is financed by the Ministry of Education of the Czech Republic.

\section{References}

[1] M. Poková, M. Cieslar, M. Slámová, Int. J. Mater. Res. 100, 391 (2009).

[2] M. Cieslar, M. Slámová, J. Uhlír, Ch. Coupeau, J. Bonneville, Kovové Materiály 45, 91 (2007).

[3] M. Cieslar, M. Slámová, M. Hájek, J. Veselý, Mater. Sci. Forum 567-568, 325 (2008).

[4] H.-W. Huang, B.-L. Ou, Mater. Design 30, 2685 (2009).

[5] M. Dehmas, P. Archambault, M. Serriere, E. Gautier, C.A. Gandin, Aluminium 78, 864 (2002).

[6] M. Slámová, P. Sláma, M. Cieslar, Mater. Sci. Forum 519-521, 365 (2006).

[7] N.A. Belov, D.G. Eskin, A.A. Askenov, Multicomponent Phase Diagrams: Application for Commercial Aluminum Alloys, Elsevier, Oxford (UK) 2005.

[8] Y.J. Li, L. Arnberg, Mater. Sci. Eng. A 347, 130 (2003).

[9] Y. Birol, J. Alloys Comp. 471, 122 (2009).

[10] T. Pettersen, Y. Li, T. Furu, K. Marthinsen, Mater. Sci. Forum 558-559, 301 (2007)
[11] D.T.L. Alexander, A.L. Greer, Acta Mater. 50, 2571 (2002).

[12] Y.J. Li, L. Arnberg, Acta Mater. 51, 3415 (2003).

[13] M. Dehmas, R. Valdes, M.-C. Lafont, J. Lacaze, B. Viguier, Scr. Mater. 55, 191 (2006).

[14] M. Dehmas, P. Weisbecker, G. Geandier, P. Archambault, E. Aeby-Gautier, J. Alloys Comp. 400, 116 (2005).

[15] Y. Birol, Scr. Mater. 59, 611 (2008).

[16] G. Gottstein, L.S. Shvindlerman, Grain Boundary Migration in Metals, CRC Press, New York 2010.

[17] O. Engler, Mater. Sci. Forum 273-275, 483 (1998).

[18] W.C. Liu, B. Radhakrishnan, Mater. Lett. 64, 1829 (2010).

[19] M. Hájek, J. Veselý, M. Cieslar, Mater. Sci. Eng. A 462, 339 (2007).

[20] G. Zhang, J.E. Morral, H.D. Brody, Mater. Sci. Eng. A 447, 217 (2007).

[21] J. Grammatikakis, K. Eftaxias, V. Hadjicontis, J. Phys. Chem. Solids 49, 1275 (1988).

[22] X. Huang, N. Hansen, N. Tsuji, Science 312, 249 (2006).

[23] X. Huang, N. Kamikawa, N. Hansen, Mater. Sci. Eng. A 483-484, 102 (2008). 